\title{
THE USE OF AUDIOVISUAL AIDS IN THE FORMATION OF COMMUNICATIVE COMPETENCE OF NON-LINGUISTIC UNIVERSITY STUDENTS
}

CKorsakova G., ORCID: 0000-0002-4361-5748, SPIN-код: 2029-7840, Ph.D., Baltic Federal University named after I. Kant, Kaliningrad, Russia, Korsakova.G.2013@yandex.ru

\section{ИСПОЛЬЗОВАНИЕ АУДИОВИЗУАЛЬНЫХ СРЕДСТВ ОБУЧЕНИЯ ПРИ ФОРМИРОВАНИИ КОММУНИКАТИВНОЙ КОМПЕТЕНЦИИ СТУДЕНТОВ НЕЯЗЫКОВОГО ВУЗА}

\author{
СКорсакова Г. Г., ORCID: 0000-0002-4361-5748, SPIN-code: 2029-7840, канд. пед. наук, \\ Балтийский федеральный университет им. И. Канта, \\ 2. Калининград, Россия, Korsakova.G.2013@yandex.ru
}

Abstract. The purpose of this article is to identify the possibilities of audiovisual means in teaching professional foreign language. To solve this problem, the article considers the ways of integration of network educational resources in the educational process, which allows to create a more effective educational environment, expands the range of topics and enriches the educational material with authentic sound and visual material. It is obvious that the use of these means of training in foreign language classes is not an absolute guarantee of the successful formation of foreign language competence. These training materials should be used purposefully and rationally, within a certain methodological system, which involves the consistent implementation of didactic principles.

Аннотация. Целью настоящей статьи является выявление возможностей аудиовизуальных средств в обучении профессиональному иностранному языку. Для решения этой задачи в статье рассматриваются способы интеграции сетевых образовательных ресурсов в учебный процесс, что позволяет создать более эффективную образовательную среду, расширяет диапазон изучаемых тем и обогащает учебный материал аутентичным звуковым и зрительным материалом. Очевидно, что использование этих средств обучения на занятиях по иностранному языку не является абсолютной гарантией успешного формирования иноязычной компетенции. Данные учебные материалы должны использоваться целенаправленно и рационально, в рамках определенной методической системы, которая предполагает последовательную реализацию дидактических принципов.

Keywords: audiovisual teaching AIDS, communicative competences, network video resources, auditory and visual perception of speech, developing tools, effective educational environment, methodological principles.

Ключевые слова: аудиовизуальные средства обучения, коммуникативные компетенции, сетевые видеоресурсы, слуховое и зрительное восприятие речи, развивающие инструменты, эффективная образовательная среда, методические принципы.

The modern educational process is characterized by a high level of informatization and the emergence of new educational technologies. These technologies are based on electronic means of information transmission, which contributes to the creation of a more effective educational environment. Especially important is the introduction of electronic educational tools in teaching a 
professional foreign language. One of the main goals of teaching students a foreign language for specific purpose is the formation of communicative competencies. These competencies involve the ability to select the language means for communication in a certain speech situation, to understand oral and written speech and reproduce its content, to build their own coherent statements. The achievement of these goals is possible only in the conditions of communicative approach of training and formation of the necessary language and speech skills in the field of listening, reading, speaking and writing. Priority in teaching a foreign language should be the development of the ability to perceive foreign language speech. This type of speech activity is one of the most difficult, and auditory skills are difficult to form. And since currently the most common sources of mediaeducational authentic information are video resources, listening training is impossible without the use of video. Under audio-visual teaching AIDS we mean "manual, designed for visual, auditory or visual-auditory perception of information contained within it" [9, p. 232]. These tools include: all kinds of recordings, audio tutorials and audio lectures; various video resources: video clips, video tutorials, video lectures; computer tutorials: electronic manuals, textbooks, test programs, computer games; audio and video resourses on the Internet.

The main directions and forms of work with audiovisual means in teaching a foreign language were analyzed in the works of domestic researchers (E. D. Patarakin [3], I. V. Pisarenko [4], E. S. Polat [5], E. N. Solovova [6], P. V. Sysoev [7], S. V. Titova [8], etc.). Scientists believe that the use of video materials in the process of teaching a foreign language helps to make the educational material more diverse and enriched with sound and visual support. This contributes not only to the improvement of listening skills, pronunciation, but also the formation of communicative competencies. In addition, the use of various channels of information (visual and auditory) contributes to the development of the perception ability of foreign language speech. In this process, the necessary psycholinguistic mechanisms are involved, such as memory, auditory and visual perception of speech, semantic structuring of statements and others. And the more successful these mechanisms are formed in students, the better they assimilate the experience of speech activity in a foreign language.

Didactic capabilities of these teaching AIDS contribute to the intensification of the educational process and stimulate students to self-study of the language according to the certain pattern. The use of audiovisual tools in teaching a foreign language allows the students to master the sound side of the language - rhythm, accent, intonation and understand the grammatical structures of the professional foreign language. Auditory and visual mechanisms help to develop skills of speaking in the studied language and to form communicative competences. Listening and speaking are closely related to each other and are part of successful communication in a foreign language. However, the fact of using educational videos in the classroom is not a guarantee of successful formation of foreign language competence. It is obvious that these training materials should be used purposefully, within a certain methodological system. According to V. I. Pisarenko "video, audio and computer materials are often used without any methodological support, which leads to a decrease in the efficiency of the educational process" [4, p. 188]. The task of the teacher is to choose the most appropriate educational resources depending on the professional specialization, the level of communicative competence of students and the topical plan. The aim of the selection of educational resources is "the choice of only those fragments that correspond to the content of the tasks and plans for a particular stage of learning a professional foreign language" [2, p. 363]. The main criterion for the selection of educational resources, first of all, is their professional orientation. The information provided should serve as an incentive for the formation of communicative competence in the field of the chosen profession. Another important selection 
criterion of the resourses is the orientation to the modern reality, which is a necessary condition for increasing motivation to learn a foreign language.

Various resourses of educational platforms from leading universities in the world may be used for the successful implementation of the objectives of teaching professional foreign language. These resourses can be found in the portals Coursera (https://www.coursera.org), EdX (https://www.edx.org), Open education (https://openedu.ru), media-TED (https://www.ted.com) as well as video podcasts - ESLpod.com (URL:https://secure3.eslpod.com/privacy), Listen A Minute (URL: https://listenaminute.com). These educational video resources allow the trainees to get acquainted not only with the text material, but also to use audio and video support of texts, video lectures, interviews, reports, presentations as well as leave comments. On these platforms, audiovisual training resources ranging from 10 to 60 minutes are publicly available. Many platforms contain interactive components and feedback to learners.

But these training materials should be used purposefully, within a certain methodological system with the implementation of the following principles:

1. Presentation of audio and video materials should be selective depending on the target setting, the language level of the trainees and the stage of training.

2. Video viewing time should be increased gradually and be accompanied by additional exercises to develop the certain language competencies.

3. Presentation of video materials, practicing listening and speaking skills should go gradually from simple to complex portion of the training material.

4. The integration of video materials into the educational process involves several stages of the educational process (preparatory, receptive, reproductive, productive), each of which is implemented with the help of an appropriate system of exercises.

When determining the stages of training, it is necessary to take into account the peculiarities of listening and the phase of information perception: motivational-incentive (setting for listening), analytical-synthetic (identification, comparison with known information, forecasting of unfamiliar linguistic and semantic units, comprehension of what was heard) and executive (reasoning as a product of understanding) [1, p. 76]. Therefore, the implementation of listening training is a certain sequence for the purpose of gradual transition from the perception of the content of the material to productive forms of using the professional language in speech practice.

The first stage of training is associated with the formation and development of the terminological vocabulary of students. The expansion of the professional dictionary is important for understanding lectures in a foreign language and viewing video clips. Students have difficulties in recognizing the terms and terminological combinations in the spoken form. Therefore, it is especially important to develop the skills of processing the speech flow in which they are pronounced during recording. To do this, lexical lists should contain not only a visual representation of terms and terminological combinations, but their sound. For better vocabulary memorization it is proposed to perform exercises aimed at the development of auditory memory, articulation and pronunciation mechanism. With their help, key professional words and phrases are repeatedly heard, and subsequently reproduced without any mistakes in speech. This can be the following exercises:

- listen to the words, determine the number of syllables;

- determine the number of sentences after listening to the text;

- listen to the sentences and write down the special terms;

- replace the new unfamiliar words with another, already known synonym;

- describe the new concept in a foreign language;

- find synonyms and antonyms, word and its definition, suitable word combinations; 
- fill in the blanks the words given below;

- determine which part of speech are these words and translate the terms into Russian;

- put the right word in a specific context.

In addition to training exercises, the teacher should include instructions for the development of training strategies: how to memorize terms and terminological phrases, reproduce what you heard, work more productively with video clips and how to maintain your own glossaries.

The next stage of the training work is related to the viewing of video clips connected with the profession. It should be noted that the training video should be based on familiar lexical material, known grammatical base and structures, as it allows students to create a special controlled speech environment in the classroom on the basis of selected and organized material. This is especially important at the initial stage of training, so that students are not discouraged by the new unfamiliar vocabulary and the inability to successfully perform the necessary tasks.

In order to check the understanding of the viewed material, exercises are offered that are aimed at discussing and understanding the general content, individual semantic segments. These tasks should be aimed at the formation of skills to extract the maximum number of different details for understanding, to highlight the main and secondary information and the most important facts. It can be the following exercises: make a short plan of the viewed video, choose the most successful title to the viewed material, reproduce the main facts of the video, determine the main problem of the message and confirm your answer with specific quotes, describe your attitude to this problem, analyze alternative points of view, formulate a final conclusion based on keywords.

At this stage of the practical training, the teacher should provide students with guidelines for the selection and analysis of information, the formation of a critical attitude to the review, the formulation of their own conclusions and concepts. Educational work of the next stage - after watching the video is aimed at the development of communicative skills, oral and written speech. The peculiarity of this stage is a gradual transition from reproductive to productive types of speech activity - speaking and writing. Students are invited to perform exercises related to the presentation of video without sound and sound dialogue on the screen, description of the frozen image, discussion of the further scenario of the event, acting as opponents, etc. This stage is aimed at the formation of creative and productive skills of students, generation and situational variation of speech statements in more complex conditions and new material. Training tasks can contain creative and search tasks based on the viewed video material and should contribute to the generalization of the information received. The following exercises may be offered to the students: prepare your own plan of the topic, following the information contained in the presentation; write a monologue on the same topic; express your comments; ask questions to each other and express your attitude to the viewed, etc. Such learning technologies will help teacher improve the language competence by enhancing vocabulary and mastering the grammatical material in the communicative way.

The final stage of work with audiovisual means of training is a reflection on the language experience through the content of the viewed materials. This reflection arises as a result of solving theoretical and practical problems at each stage of training. This stage synthesizes all the information developed by students, which develops their creative potential, their ability to critical thinking, creates an atmosphere of discussion in groups, identifies leaders in speech activity. At this stage of training the students develop the creative and productive skills, use the situational variation of speech statements in more complex conditions and new material.

Thus, the use of audiovisual means in the process of teaching a foreign language contributes to the formation of communicative competences, communication skills, as well as creates favorable conditions for the development of the algorithm of educational actions in students. The success of the use of these materials depends not only on how well organized the structure of classes, as well 
as reasonably audiovisual resources are applied within a certain methodological system. The proposed training exercises systematize the knowledge of a foreign language, as well as demand special methodology of conducting classes. The task of the teacher is to choose such training tools that are best suited for a particular training group and develop a set of additional exercises for each stage. This will serve the development of not only foreign language skills, but also communicative competencies of students.

\section{References:}

1. Zimnyaya, I. A. (1991). Psychology of teaching foreign languages in school. Moscow: Education, 219. (in Russian)

2. Korsakova, G. (2019). Electronic Textbook as an Effective Means of Teaching Professional English in a Nonlinguistic Higher School. Bulletin of Science and Practice, 5(7), 358-366. https://doi.org/10.33619/2414-2948/44/46 (in Russian).

3. Patarakin, E. D. (2015). Learning Analytic to Facilitate Group Network Collaboration. Vysshee Obrazovanie v Rossii = Higher Education in Russia, (5). 145-154. (in Russian)

4. Pisarenko, V. I. (2018). Audiovizual'nye tekhnologii v uchebnom protsesse po distsipline "Inostrannyi yazyk". In Fundamental'nye i prikladnye nauchnye issledovaniya: aktual'nye voprosy, dostizheniya i innovatsii: sbornik statei KhIV Mezhdunarodnoi nauchno-prakticheskoi konferentsii. Penza, 185-193. (in Russian)

5. Polat, E. S. (2002). Novye pedagogicheskie i informatsionnye tekhnologii $v$ sisteme obrazovaniya. Moscow. Akademiya, 224. (in Russian)

6. Solovova, E. N. (2013). Interaktivnost' v yazykovom obrazovanii. Novye tekhnologii v obrazovatel'nom prostranstve rodnogo i inostrannogo yazyka, (1). 364-370. (in Russian).

7. Sysoev, P. V. (2013). Napravleniya i perspektivy informatizatsii yazykovogo obrazovaniya. Vysshee obrazovanie v Rossii, (10). 90-97. (in Russian).

8. Titova, S. V. (2016). Didakticheskie problemy integratsii mobil'nykh prilozhenii v uchebnyi protsess. Vestnik Tambovskogo universiteta. Seriya: Gumanitarnye nauki, 21(7-8 (1591-60)). 7-14.

9. Shchukin, A. N. (2004). Obuchenie inostrannym yazykam: teoriya i praktika. Moscow. Filomatis, 416. (in Russian).

\section{Список литературы:}

1. Зимняя И. А. Психология обучения иностранным языкам в школе. М.: Просвещение, $1991.219 \mathrm{c}$.

2. Корсакова Г. Г. Электронное учебное пособие как эффективное средство обучения профессиональному английскому языку в неязыковом вузе // Бюллетень науки и практики. 2019. T. 5. №7. C. 358-366. https://doi.org/10.33619/2414-2948/44/46

3. Патаракин Е.Д. Совместная сетевая деятельность и поддерживающая ее учебная аналитика // Высшее образование в России. 2015. № 5. С. 145-154.

4. Писаренко В. И. Аудиовизуальные технологии в учебном процессе по дисциплине «Иностранный язык» // Фундаментальные и прикладные научные исследования: актуальные вопросы, достижения и инновации: сборник статей XIV Международной научнопрактической конференции. Пенза, 2018. С. 185-193.

5. Полат Е. С. Новые педагогические и информационные технологии в системе образования. М.: Академия, 2002. 224 с. (in Russian).

6. Соловова Е. Н. Интерактивность в языковом образовании // Новые технологии в образовательном пространстве родного и иностранного языка, 2013. №1. С. 364-370. 
7. Сысоев П. В. Направления и перспективы информатизации языкового образования // Высшее образование в России. 2013. № 10. С. 90-97.

8. Титова С. В. Дидактические проблемы интеграции мобильных приложении в учебныи процесс. // Вестник Тамбовского университета. Серия: Гуманитарные науки, 2016. T. 21. № 7-8 (1591- 60). С. 7-14.

9. Щукин А. Н. Обучение иностранным языкам: теория и практика. М.: Филоматис, 2004. $416 \mathrm{c}$.

Работа поступила в редакиию 26.07.2019 2.
Принята к публикациии 29.07.2019 2.

\section{Ссылка для цичтирования:}

Korsakova G. The Use of Audiovisual Aids in the Formation of Communicative Competence of Non-linguistic University Students // Бюллетень науки и практики. 2019. Т. 5. №9. С. $472-$ 477. https://doi.org/10.33619/2414-2948/46/56

Cite as (APA):

Korsakova, G. (2019). The Use of Audiovisual Aids in the Formation of Communicative Competence of Non-linguistic University Students. Bulletin of Science and Practice, 5(9), 472-477. https://doi.org/10.33619/2414-2948/46/56 (in Russian). 